\title{
A Study On Need Of Law On Preventing Sexualharassment Of Women At Work Place In India.
}

\author{
A.BEULA CHRISMAK DARIUS BBA.LLB(HONS) $1{ }^{\text {st }}$ YEAR \\ Mrs Jayasheela. G (Assistant Professor)Saveetha School Of Law \\ Saveetha University
}

\begin{abstract}
The aim of the present study "A study on need of law on preventing sexual harassment of women at work place in India is to examine and maintain a comfortable work environment for women and to know the need for a comprehensive law on preventing sexual harassment of women at workplace. The research explores various types of sexual harassment in detail and gives brief explanation of preventing sexual harassment of women at workplace. At last the research findings reveals that sexual harassment is an abuse of power .
\end{abstract}

\section{INTRODUCTION:}

Sexual harassment is defined as unwelcome sexual request for sexual favors and other conduct . Sexual harassment occurs when unwelcome conduct of a sexual nature creates a threatening environment that affects a person ability to participate in an action or when it is stated that an individual must submit to conduct if a sexual nature in order to join in a company or other things. Sexual harassment is also defined by law and the law says that it will seek to prevent such sexual harassment incidents and take corrective actions when sexual harassment occurs .There are two types of sexual harassment they are quid pro quo which means this for that in this case a individual must submit to conduct of a sexual nature in order to participate or join in a company the other type is hostile environment which means uncomfortable environment in this case when a unwelcome conduct of a sexual nature creates a threatening environment that affects a persons ability to participate in an activity. The other types of sexual harassment are unwanted sexual statementwhich means talking about ones sexual activity in front of others, unwanted personal attention which means pressure for dates where a sexual intent appears evident but remain unwanted, unwanted physical or sexual advances which means touching, hugging, kissing oneself sexually for others to view.

\section{OBJECTIVE :}

1)To examine and maintain a comfortable productive work environment for women .

2) To know the need for a comprehensive law on preventing sexual harassment of women at work place .

\section{RESEARCH GAP:}

The workplace should create a positive environment for women . They should write and implement more policy regarding prevention of sexual harassment. There should be high level management support . And there should be regular training and information to employees regarding prevention of sexual harassment .

\section{LIMITATIONS:}

1) Lack of secondary source of data .

2) Restricted accessibility to primary source of data .

\section{RESEARCH METHODOLOGY:}

The research is based on secondary source of data, which includes :

- Articles.

- Book .

- Journals .

a) TYPES OF RESEARCH :

* Applied research. 


\section{REVIEW OF LITERATURE}

1) Graeme Lockwood (2011) : The author explains with the help of secondary source of data discussed about prevention of sexual harassment. The author discuss about the organizational and legal context in which parties involved in claims relating to sexual harassment. The author briefly explains about the parties involved in claims relating to sexual harassment .

2) Kamal H Hassan (2015 ): The author explains about the legal provisions on sexual harassment in the workplace. The author also have briefly explained about the guidelines for prevention of sexual harassment .

3) Maheensalmon ( 2016 ) :The authorexplains the impact of sexual harassment on employee turnover intention in educational sectors. The researcher also suggest strong interventions to reduce the sexual harassment in order to retain employees and enable them to work efficiently .

\section{HYPOTHESIS:}

HO:There is no significant change in the problem associated with sexual harassment.

H1:There are significant changes in the problem associated with sexual harassment .

1. CHAPTER 1: To examine and maintain a comfortable productive work environment for women :

To maintain a comfortable productive work environment for women they should adopt a clear prevention of sexual harassment of policy. They should explain their employees that they have the freedom of right to work free from sexual harassment so they feel comfortable. They should monitor their workplace and get out among their employees periodically and talk to their employees about their work environment. They should keep the lines of communication open. They should take all the complaints seriously and act immediately to investigate the complaints. If complaints turns to be valid their response should be effective . This is how they should maintain a comfortable and productive work environment for women at workplace .

\section{CHAPTER 2: To know the need for a comprehensive law on prevention of sexual harassment of} women at work place :

The need for a comprehensive law on preventing of sexual harassment on women at work place is the law will be applied to all women harassed in the workplace or any other place. The women may or may not be employed and can be of any age. This law will be applicable to all women and women only. If the women is harassed a complaint can be filled under this Act. This Act requires all workplace to setup internal complaint committee to address the issues of sexual harassment. There is also local complaint committee for each districts were complaints can b filled. Under this Act an aggrieved women can file a complaint within 3 months of the incident. The Act provides the option of a settlement between the aggrieved women and the respond through conciliation but only on the request of the women . Under this Act the inquiry has to be completed within 90 days . In case of malicious complaints the committees may take action against the women. Under this Act the identity of the aggrieved women respondent wittiness as well as other details of the complaint cannot be published to the media. The Act also helps the employer to provide a safe working environment $\mathrm{o}$ all employees . All workplaces are mandated by law to provide a safe and secure working environment to women free from sexual harassment There are other laws for protecting women from sexual harassment but they should implement more effective laws to protect women from sexual harassment at work place. This is the need for a comprehensive law on preventing sexual harassment of women at work place .

VIII. STATISTICAL DATA :

Number of sexual harassment cases reported by top companies :

\begin{tabular}{|l|l|l|}
\hline COMPANIES & NO:OF CASES & YOY\% CHANGE \\
\hline Wipro & 111 & 11.0 \\
\hline ICICI Bank & 87 & -7.4 \\
\hline Infosys & 62 & 17.0 \\
\hline TCS & 34 & 100.0 \\
\hline Axis Bank & 32 & -5.9 \\
\hline SBI & 27 & 92.9 \\
\hline Tech Mahindra & 26 & NA \\
\hline Tata Steel & 18 & -25.0 \\
\hline Cipla & 14 & -17.6 \\
\hline
\end{tabular}




\section{FINDINGS :}

1) There is no positive workplace environment for women's .

2) There is no encouragement on appropriate conduct of managers regarding prevention of sexual harassment .

3) There is no policy regarding implementation of prohibiting sexual harassment of women at work place There is no high level management support .

4) There is no regular training and information on preventing sexual harassment to all staff and management .

\section{SUGGESTIONS :}

1) There should be positive workplace environment for women's .

2) The employees should encourage the appropriate conduct of managers taken regarding the prevention of sexual harassment .

3) They should write and implement prevention of sexual harassment policy .

4) There should be high level management support .

5) There should be regular training and information on preventing sexual harassment to all staff and management .

\section{CONCLUSION :}

Therefore I conclude that sexual harassment is not a harmless comments or horseplay it deprives other dignity and equality . Victims of sexual harassment have well established rights under federal law and in many cases. Sexual harassment is a form of gender discrimination. More comprehensive laws gives us specific rights and remedies if you experience sexual harassment in the work place. Sexual harassment is not just illegal it is harmful also . The most common injuries suffered by victims of sexual harassment are emotions . Victims of sexual harassment often feels powerless and they develop low self esteem . Bringing comprehensive laws gives us power to fight back against sexual harassment. We have the right to be free from sexual harassment and we have the right to be treated with dignity and respect and we don't need to tolerate sexual harassment . Therefore there should be more laws pertaining to prevention and control of sexual harassment of women at work place and the management should also take some positive measures to prevent sexual harassment of women at work place.

\section{BIBLIOGRAPHY}

1) Graeme Lockwood, Patrice Rosenthal, Alexandra Budjnaovcanin, "A quantitative and qualitative analysis of sexual harassment claims"Article in industrial relations journal, January 2011 .

2) Maheensalman , Fahad Abdullah, AfiaSaleem, "Sexual harassment at workplace and its impact on employee turnover intentions" April 2016 .

3) Kamal H Hassan, YeeZing Lee, " sexual harassment at work place and new legal provisions" June 2015.

4) JashpalKaur Bhatt, "Sexual harassment in the workplacelegal redress for a gendered issue" June 2017 . 